\title{
Stethoscope, Hands, and Mobile Phone: Bacterial Contamination and Infection Control among Medical and Nursing Students in Jordan
}

\author{
Stetoskop, El ve Cep Telefonu: Ürdün'deki Tıp ve Hemşirelik Öğrencilerinde Bakteriyel \\ Kontaminasyon ve Enfeksiyon Kontrolü
}

\author{
(1) Nesreen BATAINEH ${ }^{1}$, ๑ Waleed AI MOMANII ${ }^{1}$, ( Luai Abu-ISMAIL ${ }^{2}$, ๑ Almu'atasim KHAMEES ${ }^{2}$, ๑ Ismail MALKAWI ${ }^{3}$, \\ (1) Dima Abu ISMAIL ${ }^{4}$, ๑ Leen AI MOMANI ${ }^{5}$, (1) Moawia KHATABEH ${ }^{1}$, (1) Muthanna SARAIREH ${ }^{2}$ \\ 1 Yarmouk University Faculty of Medicine, Department of Basic Medical Sciences, Irbid, Jordan \\ 2 Yarmouk University Faculty of Medicine, Department of Clinical Medical Sciences, Irbid, Jordan \\ 3Jordan University of Science and Technology, Faculty of Veterinary Medicine, Department of Basic Veterinary Medical Sciences, Irbid, Jordan \\ ${ }^{4}$ Hashemite University Faculty of Medicine, Department of Clinical Medical Sciences, Zarqa, Jordan \\ 5 Jordan University of Science and Technology Faculty of Medicine, Department of Basic Medical Sciences, Irbid, Jordan
}

\section{Abstract}

Introduction: This study aimed to investigate the antibiotic susceptibility of bacterial contamination that is present on stethoscopes, mobile phones, and hands along with the level of self-reported cleaning practices among medical students.

Materials and Methods: Eighty-seven swabs from stethoscopes, mobile phones, and hands were collected from volunteering medical ( $\mathrm{n}=66$, $75.8 \%)$ and nursing students $(n=21,24.2 \%)$ in a hospital environment. The swabs were collected and transported to the microbiology laboratory and cultured on appropriate media. The isolated bacteria were identified as per standard microbiological procedures.

Results: Five bacterial species were isolated and identified. The highest contamination was found on hands (37\%), mobile phones (32\%), and stethoscopes (31\%). Isolates were highly resistant to most tested antibiotics. Only seven (8\%) students cleaned their stethoscopes between patients and more alarmingly, 33 (38\%) did not clean their stethoscopes at all, and 58 (67\%) did not know how to effectively clean their stethoscopes. The current study revealed a gap between the students' knowledge and their proper hygienic practice in hospitals.

Conclusion: The hands are a major source of pathogenic bacteria and have higher bacterial contamination than stethoscopes and mobile phones. It highlights the need for increasing awareness among students and healthcare professionals about the importance of disinfecting medical devices, mobile phones, and hands in hospitals.

Keywords: Medical students, nursing students, stethoscope, mobile phone, hand hygiene, nosocomial infection

Giriş: Çalışmanın temel amacı, tıp öğrencilerinde stetoskop, cep telefonu ve ellerde bulunan bakteriyel kontaminasyonun antibiyotik duyarlılıkları ile birlikte öğrencilerin kendi bildirdiği temizlik uygulamaları düzeyini araştırmaktır.

Gereç ve Yöntem: Hastane ortamında gönüllü tıp öğrencilerinin ( $n=66, \% 75,8)$ ve hemşirelik öğrencilerinin $(n=21, \% 24,2)$ stetoskop, cep telefonu ve elinden 87 sürüntü örneği alındı. Sürüntü örnekleri toplanarak mikrobiyoloji laboratuvarına nakledildi ve uygun besiyerlerinde kültüre edildi. İzole edilen bakteriler, standart mikrobiyolojik prosedürlere göre tanımlandı.

Bulgular: Beş bakteri türü izole edildi ve tanımlandı. En yüksek kontaminasyon ellerde (\%37) bulundu ve takiben cep telefonlarında (\%32) ve stetoskoplarda (\%31) bulundu. İzolatlar, test edilen çoğu antibiyotiğe karşı oldukça dirençliydi. Öğrencilerin sadece yedisi (\%8) hastalar arasında stetoskoplarını temizlemekteydi ve daha da endişe verici bir şekilde 33'ü (\%38) stetoskoplarını hiç temizlemiyordu. Elli sekizi (\%67) stetoskoplarını

Cite this article as: Bataineh N, Al Momani W, Abu-Ismail L, Khamees A, Malkawi I, Ismail DA, Al Momani L, Khatabeh M, Saraireh M. Stethoscope, Hands, and Mobile Phone: Bacterial Contamination and Infection Control among Medical and Nursing Students in Jordan. Mediterr J Infect Microb Antimicrob. 2022;11:8. 
etkili bir şekilde nasıl temizleyeceğini bilmiyordu. Mevcut çalışma, öğrencilerin bilgileri ile hastanelerdeki uygun hijyen uygulamaları arasında bir boşluk olduğunu göstermektedir.

Sonuç: Eller, patojenik bakterilerin ana kaynağıdır ve stetoskoplar ve cep telefonlarından daha yüksek bakteriyel kontaminasyona sahiptir. Hastanelerde tıbbi cihazların, cep telefonlarının ve ellerin dezenfekte edilmesinin önemi konusunda öğrenciler ve sağlık çalışanlarında farkındalığın artırılması gerekmektedir.

Anahtar Kelimeler: Tıp öğrencileri, hemşirelik öğrencileri, stetoskop, cep telefonu, el hijyeni, hastane enfeksiyonu

\section{Introduction}

Healthcare-associated infections (HCAls) affect hundreds of millions of individuals worldwide and represent a significant threat to patient safety ${ }^{[1]}$. Healthcare-associated infections result in increased mortality and morbidity, a greater length of hospital stay, and higher healthcare $\operatorname{costs}^{[2]}$. Studies have indicated that healthcare workers' hands are the main route of cross-transmission ${ }^{[3]}$, and provide convincing evidence that hand hygiene improvement reduces rates of $\mathrm{HCAls}^{[4]}$. Hand hygiene is the simplest and most cost-effective way to reduce HCAl transmission incidences ${ }^{[3]}$, especially antimicrobialresistant pathogens ${ }^{[5]}$. A stethoscope is a medical tool that has been at the core of infection control studies and identified as a potential vector for bacterial infection transmission for over 30 years ${ }^{[6]}$. Studies from developed countries revealed that a major proportion of healthcare professionals do not maintain the proper hygiene of their stethoscopes, resulting in the transmission of serious pathogenic bacteria, such as methicillinresistant Staphylococcus aureus, vancomycin-resistant Enterococci, Clostridioides difficile, Pseudomonas aeruginosa, and Klebsiella species ${ }^{[7]}$.

However, the massive and widespread use of modern technology in medicine and its role in improving healthcare services could represent an additional piece of the complex puzzle of infection control in hospital wards. The methods of infection spread in healthcare facilities have been noted to become more diverse. Using mobile phones as a method of communication and a source of information in our lives is an important example to be considered. Many studies have confirmed that a mobile phone is a reservoir for nosocomial infections, including multidrugresistant bacteria ${ }^{[8]}$. A previous study reported that $>90 \%$ of the cell phones of healthcare workers were contaminated with microorganisms and $>14 \%$ of them carried pathogenic bacteria that commonly cause nosocomial infections $s^{[9]}$. Pathogenic bacteria were detected with multiple antibiotic resistance (MAR) indices, where hands and mobile phones can act as a carrier for infectious disease transmission ${ }^{[10]}$.

However, little attention has been given to the student's hygienic practice in disinfecting stethoscopes, mobile phones, and hands within the clinical or educational setting. Therefore, we investigated the relationship between the students' hand hygiene, stethoscope, and mobile phone disinfection and the rate of bacterial contamination to improve their understanding of hygiene practices. Additionally, this study aimed to determine the susceptibility to antimicrobials of bacterial isolates and associate the results with self-reported cleaning practices among medical students.

\section{Materials and Methods}

\section{Sample Collection}

From October to December 2019, a station was established to collect 261 swabs from 87 volunteers medical $(n=66,75.8 \%)$ and nursing $(n=21,24.2 \%)$ students who participated in the survey at Princess Rahmah Teaching Hospital as per standard aseptic procedures. Princess Rahmah Teaching Hospital is specialized in pediatric medicine and surgery that receives cases from the age of 1 day to 14 years. It is the referral hospital in the northern region of Jordan and is located at Princess Badiaa Hospital campus. Collectively, these two hospitals have a capacity of 400 beds. It is a teaching hospital that trains students of medicine, pharmacy, and nursing in governmental and private colleges and institutes. Additionally, the hospital has an auditorium that is equipped for educational purposes, which can accommodate nearly 100 persons. To the best of our knowledge, no previous studies have been reported in Princess Rahmah Teaching Hospital actual staff knowledge and practice of hygiene during their clinical rounds. No education has been given to the student's hygienic practice in disinfecting stethoscopes, mobile phones, and hands within the clinical or educational setting before they start their clinical ward practice.

The diaphragm of the stethoscope $(n=87)$, the surface of the mobile phone $(n=87)$, and the dominant hand $(n=87)$ of each student were swabbed using a separate sterile cotton swab for each specimen. A self-administered survey was collected along with the samples to evaluate their knowledge. The study participants include medical and nursing students who are undergoing hospital clinical training.

\section{Bacterial Isolation}

The swabs were collected in Stuarts transport medium and transported to the lab within 1 hour. Each swab was enriched in $10 \mathrm{ml}$ Mueller-Hinton broth (Oxoid, USA) and aerobically incubated at $37{ }^{\circ} \mathrm{C}$ for $24 \mathrm{~h}$. After incubation, a loopful was streaked on blood agar and MacConkey agar (Oxoid, USA) and aerobically incubated at $37{ }^{\circ} \mathrm{C}$ for $24 \mathrm{~h}$. All media used 
in this study were prepared according to the manufacturer's instructions and sterilized by autoclaving at $121^{\circ} \mathrm{C}$ for $15 \mathrm{~min}$.

\section{Bacterial Isolate Identification}

Every plate was observed after incubation. Colony morphology was examined and recorded based on the size, form, pigmentation, margin, elevation, and opacity. The pure colony of each isolate was picked and identified by cellular characteristics after gram staining. Gram-positive cocci were identified by conventional methods, i.e., catalase, coagulase, esculin hydrolysis in the presence of $40 \%$ bile, and susceptibility to novobiocin and bacitracin. Gram-negative cells that are grown on MacConkey agar were identified according to test results for motility, triple sugar iron agar, indole, methyl red, Voges proskauer, and citrate.

\section{Preservation of Isolates}

A separate colony from each identified isolate was enriched in $10 \mathrm{ml}$ Mueller-Hinton broth and aerobically incubated at $37{ }^{\circ} \mathrm{C}$. After incubation, the McFarland 2.0 turbidity standard $\left(\sim 6 \times 10^{8} \mathrm{CFU} / \mathrm{ml}\right)$ was taken as a reference to adjust the turbidity of bacterial suspensions. Then, $700 \mu \mathrm{l}$ of the cultures were introduced to $300 \mu \mathrm{l}$ sterile glycerol and kept at $-70{ }^{\circ} \mathrm{C}$ until further testing.

\section{Antimicrobial Susceptibility Tests}

Susceptibility to antimicrobial agents was evaluated using the disk diffusion method, according to the Clinical and Laboratory Standard Institute (CLSI, 2016) guidelines. The following antimicrobials were tested: ciprofloxacin $(5 \mu \mathrm{g})$, ampicillin (10 $\mu \mathrm{g})$, norfloxacin $(10 \mu \mathrm{g})$, erythromycin $(15 \mu \mathrm{g})$, chloramphenicol $(30 \mu \mathrm{g})$, gentamicin $(10 \mu \mathrm{g})$, tetracycline $(30 \mu \mathrm{g})$, vancomycin $(30 \mu \mathrm{g})$, amoxicillin/clavulanic acid $(20 / 10 \mu \mathrm{g})$, cefepime (30 $\mu \mathrm{g})$, penicillin $(10 \mu \mathrm{g})$, clindamycin $(2 \mu \mathrm{g})$, trimethoprimsulfamethoxazole $(1.25 / 23.75 \mu \mathrm{g})$, and oxacillin $(1 \mu \mathrm{g})$. Briefly, few colonies of the isolate to be tested were suspended in saline to density visually equivalent to that of " $0.5 \mathrm{McFarland}$ standards. A swab of the cell suspension was then spread in three directions on the entire surface of a Mueller Hinton Agar plate, and antibiotic disks were applied onto the agar. The agar plates were then incubated at $35{ }^{\circ} \mathrm{C}$ for $18-24$ h. S. aureus (ATCC25923) was bought lyophilized from a local supplier and used as a control. Multidrug resistance (MDR) bacteria were considered when an isolate was resistant to 3 of the used antimicrobials in this study ${ }^{[11]}$.

\section{Statistical Analysis}

The self-administered survey was analyzed using an Excel program that shows the descriptive values of responses regarding knowledge about cleaning the stethoscope, mobile phone, and hand. Data were summarized as frequencies and proportions and were compared using the chi-square test.
Logistic regression models were fitted to identify the associated factors with a poor score (a score $<1$ ). All tests were two-sided, and statistical significance was considered at a $p$ value of $<0.05$. The data entry and statistical analysis were performed using the Statistical Package for the Social Sciences (SPSS) (IBM SPSS Corp, SPSS Statistics ver. 25, USA).

\section{Results}

This study included 87 medical $(66,76 \%)$ and nursing $(21,24 \%)$ students. Demographic characteristics were divided as follows: 35 males (40\%) and 52 females (60\%) aged between 20-24 years. Only seven (8\%) students cleaned their stethoscopes after every patient, whereas 33 (38\%) did not. The remaining students showed a variable frequency of cleaning their stethoscopes (Table 1).

Alcohol was the most popular method of cleaning the stethoscopes in 30 (34\%) students, followed by alcohol-free wet wipes 17 (20\%). Surprisingly, 26 (30\%) students did not use anything to clean their stethoscopes (Table 1). The stethoscopes were considered an infection hazard in 68 students (78.2\%) and 67 (77\%) stated the importance to have their stethoscopes always clean; however, 58 (67\%) did not know how to effectively clean their stethoscopes and $11(13 \%)$ stated that they saw others cleaning their stethoscopes. Remarkably, 51 students (59\%) agreed to have enough time to clean their stethoscopes, whereas 36 (41\%) agreed that cleaning equipment was available in the hospitals. Of the students, 80 (92\%) students acknowledged that they did not have this experience in lectures at the university or any training online about cleaning their stethoscopes (Table 2). Most students (78\%) washed their hands after the patient encounter. Most of the students (86\%) used

Table 1. Cleaning stethoscopes frequency and method used by the students

\begin{tabular}{ll}
\hline \multicolumn{2}{l}{ How frequently do you clean your stethoscope? } \\
\hline Frequency & No (\%) \\
\hline After every patient & $7(8.0)$ \\
\hline More than once daily & $2(2.3)$ \\
\hline Once daily & $13(14.9)$ \\
\hline Once weekly & $24(27.6)$ \\
\hline Once monthly & $8(9.3)$ \\
\hline Never & $33(37.9)$ \\
\hline Methods for cleaning stethoscope & \\
\hline Method & No (\%) \\
\hline Nothing & $26(30.0)$ \\
\hline Water & $3(3.5)$ \\
\hline Hygiene or wet wipes & $17(19.5)$ \\
\hline Alcohol & $30(34.4)$ \\
\hline Dry cotton or fine or tissue & $11(12.6)$ \\
\hline
\end{tabular}


Table 2. Cross-tabulation analysis of the differences in attitudes between nursing and medical students

\begin{tabular}{|c|c|c|c|}
\hline \multirow{2}{*}{ Variable } & \multicolumn{2}{|l|}{ Specialty } & \multirow{2}{*}{ p value } \\
\hline & Nursing (\%) & Medical (\%) & \\
\hline I am confident that I know how to properly clean my stethoscope & & & 0.010 \\
\hline Disagree & $2(9.5)$ & $27(40.9)$ & \\
\hline Neutral & $4(19.0)$ & $15(22.7)$ & \\
\hline Agree & $15(71.5)$ & $24(36.4)$ & \\
\hline My cleaning equipment is readily available & & & 0.005 \\
\hline Disagree & $3(14.3)$ & $29(43.9)$ & \\
\hline Neutral & $3(14.3)$ & $16(24.2)$ & \\
\hline Agree & $15(71.4)$ & $21(31.9)$ & \\
\hline I regularly see others cleaning their stethoscopes & & & 0.001 \\
\hline Disagree & $10(47.6)$ & $57(87.7)$ & \\
\hline Neutral & $3(14.3)$ & $5(7.7)$ & \\
\hline Agree & $8(38.1)$ & $3(4.6)$ & \\
\hline I must make sure my stethoscope is clean & & & 0.033 \\
\hline Disagree & $5(23.8)$ & $5(7.6)$ & \\
\hline Neutral & $0(0.0)$ & $10(15.2)$ & \\
\hline Agree & $16(76.2)$ & $51(77.3)$ & \\
\hline \multicolumn{3}{|c|}{ Before completing this survey I had considered stethoscopes as an infection hazard } & 0.460 \\
\hline Disagree & $4(19.0)$ & $6(9.1)$ & \\
\hline Neutral & $2(9.5)$ & $7(10.6)$ & \\
\hline Agree & 15 (71.4) & $53(80.3)$ & \\
\hline
\end{tabular}

their mobile phones during clinical rotations with only $29 \%$ of them cleaning them after the rotations (Table 2).

A cross-tabulation analysis was performed to assess the difference in attitudes between nursing and medical students and revealed significant statistical differences as shown in Table 2. Approximately, 72\% of nursing students perceived being confident in knowing how to properly clean their stethoscopes compared to $36 \%$ of medical students ( $p$ value $=0.010$ ). Furthermore, approximately $71 \%$ of nursing students reported that cleaning equipment was readily available compared to $32 \%$ of medical students ( $p$ value $=0.001$ ).

Another cross-tabulation analysis was performed to assess the difference in practice and bacterial isolates from participants' stethoscopes. Interestingly, 57\% of nursing students perceived knowing how to effectively clean their stethoscopes compared to approximately 26\% among medical students ( $p$ value $=0.008$ ). The percentage of nursing students who have attended lectures or training sessions on how to clean stethoscopes was more than that for medical students ( $p$ value=0.33). Concerning the type of bacterial isolates, approximately $36 \%$ of medical students clean their stethoscopes (no bacterial species) compared to only approximately $5 \%$ of nursing students ( $p$ value $=0.021$ ). These results are illustrated in Table 3.
Bacterial species were isolated from 62 (71\%) of the 87 tested students. A total of 131 bacterial isolates were identified and tested for their antibiotic susceptibility, and 87 mobile phones, 87 stethoscopes, and 87 dominant hands of medical and nursing students were tested. Of these, 42 (32\%) mobile phones [42 bacterial isolates recovered from 87 mobile phones of students were coagulase-negative Staphylococcus (CoNS) (28\%), followed by S. aureus (13\%) and E. coli (1\%)], 40 (31\%) stethoscopes [40 bacterial isolates were CoNS (31\%), S. aureus $(8 \%)$ and P. mirabilis (1\%)], and 49 (37\%) dominant hands [49 bacterial isolates were CoNS (40\%), S. aureus (8\%) and $K$. pneumoniae (1\%)] showed contamination with one or more types of microorganisms (Table 4). Twenty-nine $S$. aureus isolates (mobile phones 13, stethoscopes 8, and hands 8) showed a high rate of resistance to penicillin (26; 90\%), ampicillin (26;90\%), methicillin $(27 ; 93 \%)$, and erythromycin $(18 ; 62 \%)$ (Table 4). Two $S$. aureus isolates were resistant to 8 of the 14 antibiotics tested. One of them was from a mobile phone and was resistant to methicillin, erythromycin, ciprofloxacin, norfloxacin, trimethoprim/sulphamethoxazole, tetracycline, penicillin, and ampicillin, whereas the other one was from a stethoscope and was resistant to methicillin, oxacillin, erythromycin, amoxicillin/ clavulanic acid, vancomycin, cefepime, penicillin, and ampicillin. Five (17.2\%) isolates were resistant to 7 out of 14 antibiotics, three of them were resistant to 7 out of 14 antibiotics: one 
Table 3. Cross-tabulation analysis of the differences in practice and bacterial isolates from the stethoscope of nursing and medical students

\begin{tabular}{|c|c|c|c|}
\hline \multirow{2}{*}{ Variable } & \multicolumn{2}{|l|}{ Specialty } & \multirow{2}{*}{ p value } \\
\hline & Nursing (\%) & Medical (\%) & \\
\hline Do you wash your hands after you examine patients? & & & 0.391 \\
\hline No & $6(28.6)$ & $13(19.7)$ & \\
\hline Yes & $15(71.4)$ & $53(80.3)$ & \\
\hline Do you know how to clean your stethoscope effectively? & & & 0.008 \\
\hline No & $9(42.9)$ & $49(74.2)$ & \\
\hline Yes & $12(57.1)$ & $17(25.8)$ & \\
\hline Did you attend any lecture or training session about how to clean your & cope? & & 0.033 \\
\hline No & $17(81.0)$ & $63(92.0)$ & \\
\hline Yes & $4(19.0)$ & $3(8.0)$ & \\
\hline Do you use your mobile phone during rotations? & & & 0.940 \\
\hline No & $3(14.3)$ & $9(13.6)$ & \\
\hline Yes & $18(85.7)$ & $57(86.4)$ & \\
\hline Do you clean your mobile phone after using it while in your rotations? & & & 0.593 \\
\hline No & $14(66.7)$ & $48(72.7)$ & \\
\hline Yes & $7(33.3)$ & $18(27.3)$ & \\
\hline Type of isolate & & & 0.021 \\
\hline None & $1(4.8)$ & $24(36.4)$ & \\
\hline Gram (-) & $0(0.0)$ & $0(0.0)$ & \\
\hline Gram (+) & $19(90.4)$ & $40(60.6)$ & \\
\hline Both Gram (+) and Gram (-) & $1(4.8)$ & $2(3.0)$ & \\
\hline
\end{tabular}

from the hands and was resistant to methicillin, oxacillin, erythromycin, tetracycline, chloramphenicol, penicillin, and ampicillin; one from the phone and was resistant to methicillin, oxacillin, erythromycin, trimethoprim/sulphamethoxazole, cefepime, penicillin, and ampicillin; and one from the stethoscope and was resistant to methicillin, erythromycin, amoxicillin/clavulanic acid, trimethoprim/sulphamethoxazole, cefepime, penicillin, and ampicillin.

As shown in Table 5, isolates that are resistant to three out of 14 antibiotics in at least 25 (86\%) isolates. Interestingly, four $(50 \%)$ hand isolates showed resistance to at least six antibiotics, five (40\%) phone isolates to at least five antibiotics, whereas three (38\%) stethoscope isolates to at least five antibiotics out of 14. One isolate of the hand was resistant to ciprofloxacin antibiotic and two for trimethoprim/sulphamethoxazole. The antibiotics, which were effective against all stethoscope isolates include chloramphenicol, tetracycline, vancomycin, norfloxacin, and ciprofloxacin. The antibiotics that were effective against all mobile phone isolates include tetracycline, ciprofloxacin, and gentamicin. Contrarily, penicillin and ampicillin were not effective at all for all mobile phone isolates. The antibiotics that were effective against all hand isolates include vancomycin and gentamicin only. All hand and stethoscope isolates were resistant to methicillin. Only four antibiotics, gentamicin, vancomycin, ciprofloxacin, and norfloxacin, out of the 14 used antibiotics appeared to be effective against 28 (97\%) isolates

Table 4. The distribution of the isolated bacteria from stethoscope, phone, and hands

\begin{tabular}{llllll}
\hline & & Stethoscope & Phone & Hand & Total \\
\hline \multirow{2}{*}{ Gram-positive } & S. aureus & 8 & 13 & 8 & $29(22.1 \%)$ \\
\cline { 2 - 6 } & CoNS & 31 & 28 & 40 & $99(75.6 \%)$ \\
\multirow{3}{*}{ Gram-negative } & E. coli & 0 & 1 & 0 & 1 \\
\cline { 2 - 6 } & Klebsiella & 0 & 0 & 0 & \\
\cline { 2 - 6 } & Proteus & 1 & 0 & $49(37.4 \%)$ & $131(100 \%)$ \\
\hline
\end{tabular}

CoNS: Coagulase negative staphylococcus, S. aureus: Staphylococcus aureus 
Table 5. Antimicrobial susceptibility of the isolated $S$. aureus and coagulase-negative Staphylococcus bacteria to 14 antimicrobials

\begin{tabular}{|c|c|c|c|c|c|c|c|c|c|c|c|c|}
\hline \multirow{3}{*}{ Antibiotics } & \multicolumn{12}{|c|}{ S. aureus $(\mathrm{n}=29)$} \\
\hline & \multicolumn{3}{|c|}{ Stethoscope $(n=8)$} & \multicolumn{3}{|c|}{ Phone $(n=13)$} & \multicolumn{3}{|c|}{ Hand $(n=8)$} & \multicolumn{3}{|c|}{ Total $(n=29)$} \\
\hline & $S$ & $\mathbf{R}$ & I & $S$ & $\mathbf{R}$ & I & $S$ & $\mathbf{R}$ & I & $S$ & $\mathbf{R}$ & I \\
\hline$P$ & 1 & 7 & 0 & 0 & 13 & 0 & 2 & 6 & 0 & 3 & 26 & 0 \\
\hline AMP & 1 & 7 & 0 & 0 & 13 & 0 & 2 & 6 & 0 & 3 & 26 & 0 \\
\hline C & 8 & 0 & 0 & 11 & 2 & 0 & 6 & 2 & 0 & 25 & 4 & 0 \\
\hline$T$ & 8 & 0 & 0 & 13 & 0 & 0 & 4 & 4 & 0 & 25 & 4 & 0 \\
\hline FEP & 7 & 1 & 0 & 11 & 2 & 0 & 6 & 0 & 2 & 25 & 2 & 2 \\
\hline VA & 8 & 0 & 0 & 12 & 1 & 0 & 8 & 0 & 0 & 28 & 1 & 0 \\
\hline SXT & 7 & 1 & 0 & 12 & 1 & 0 & 6 & 2 & 0 & 25 & 4 & 0 \\
\hline NOR & 8 & 0 & 0 & 12 & 0 & 1 & 7 & 1 & 0 & 27 & 1 & 1 \\
\hline AMC & 7 & 1 & 0 & 10 & 3 & 0 & 6 & 2 & 0 & 23 & 6 & 0 \\
\hline CIP & 8 & 0 & 0 & 13 & 0 & 0 & 6 & 1 & 1 & 27 & 1 & 1 \\
\hline $\mathrm{CN}$ & 7 & 1 & 0 & 13 & 0 & 0 & 8 & 0 & 0 & 28 & 1 & 0 \\
\hline$E$ & 1 & 7 & 0 & 7 & 6 & 0 & 3 & 5 & 0 & 11 & 18 & 0 \\
\hline $0 X$ & 7 & 1 & 0 & 8 & 4 & 1 & 6 & 1 & 1 & 21 & 6 & 2 \\
\hline $\mathrm{ME}$ & 0 & 8 & 0 & 0 & 11 & 2 & 0 & 8 & 0 & 0 & 27 & 2 \\
\hline \multirow[t]{3}{*}{ Antibiotics } & \multicolumn{12}{|c|}{ CoNS $(n=99)$} \\
\hline & \multicolumn{3}{|c|}{ Stethoscope $(n=31)$} & \multicolumn{3}{|c|}{ Phone $(n=28)$} & \multicolumn{3}{|c|}{ Hand $(n=40)$} & \multicolumn{3}{|c|}{ Total $(n=99)$} \\
\hline & $\mathrm{S}$ & $\mathbf{R}$ & $I$ & $S$ & R & $I$ & $S$ & R & $I$ & $S$ & R & I \\
\hline$P$ & 5 & 26 & 0 & 7 & 21 & 0 & 6 & 34 & 0 & 18 & 81 & 0 \\
\hline AMP & 4 & 27 & 0 & 7 & 21 & 0 & 3 & 37 & 0 & 14 & 85 & 0 \\
\hline C & 31 & 0 & 0 & 25 & 3 & 0 & 40 & 0 & 0 & 96 & 3 & 0 \\
\hline$T$ & 27 & 4 & 0 & 26 & 2 & 0 & 34 & 6 & 0 & 87 & 12 & 0 \\
\hline FEP & 27 & 2 & 2 & 24 & 2 & 2 & 35 & 3 & 2 & 86 & 7 & 6 \\
\hline VA & 30 & 1 & 0 & 28 & 0 & 0 & 37 & 3 & 0 & 95 & 4 & 0 \\
\hline SXT & 20 & 10 & 1 & 26 & 0 & 2 & 30 & 8 & 2 & 76 & 18 & 5 \\
\hline NOR & 28 & 2 & 1 & 27 & 1 & 0 & 38 & 1 & 1 & 94 & 4 & 1 \\
\hline AMC & 25 & 6 & 0 & 25 & 3 & 0 & 34 & 6 & 0 & 84 & 15 & 0 \\
\hline CIP & 24 & 3 & 4 & 27 & 1 & 0 & 38 & 1 & 1 & 89 & 5 & 5 \\
\hline $\mathrm{CN}$ & 29 & 1 & 1 & 26 & 1 & 1 & 37 & 2 & 1 & 92 & 4 & 3 \\
\hline$E$ & 6 & 24 & 1 & 12 & 15 & 1 & 8 & 27 & 5 & 26 & 66 & 7 \\
\hline $0 x$ & 17 & 14 & 0 & 17 & 11 & 0 & 19 & 20 & 1 & 53 & 45 & 1 \\
\hline ME & 0 & 27 & 4 & 0 & 24 & 4 & 0 & 33 & 7 & 0 & 84 & 15 \\
\hline
\end{tabular}

CoNS: Coagulase-negative staphylococcus, S. aureus: Staphylococcus aureus, P: Penicillin, AMP: Ampicillin, C: Chloramphenicol, T: Tetracycline, FEP: Cefepime, VA: Vancomycin, SXT: Trimethoprim/sulphamethoxazole, NOR: norfloxacin, AMC: Amoxicillin/clavulanic acid, CIP: ciprofloxacin, CN: Gentamicin, E: Erythromycin, OX: Oxacillin, ME: Methicillin

Table 6. The distribution of isolated bacteria on the stethoscope, mobile phone, and hands

\begin{tabular}{lllll}
\hline & CoNS & Percent (\%) & S. aureus & Percent (\%) \\
\hline Stethoscope & 31 & $31.3 \%$ & 8 & $27.5 \%$ \\
\hline Phone & 28 & $28.3 \%$ & 13 & $45 \%$ \\
\hline Hand & 40 & $40.4 \%$ & 8 & $27.5 \%$ \\
\hline Total & 99 & $100 \%$ & 29 & $100 \%$ \\
\hline
\end{tabular}


Table 7. Multiple antimicrobial-resistant (MAR index) of the isolated bacteria to the tested antibiotics $(n=14)$

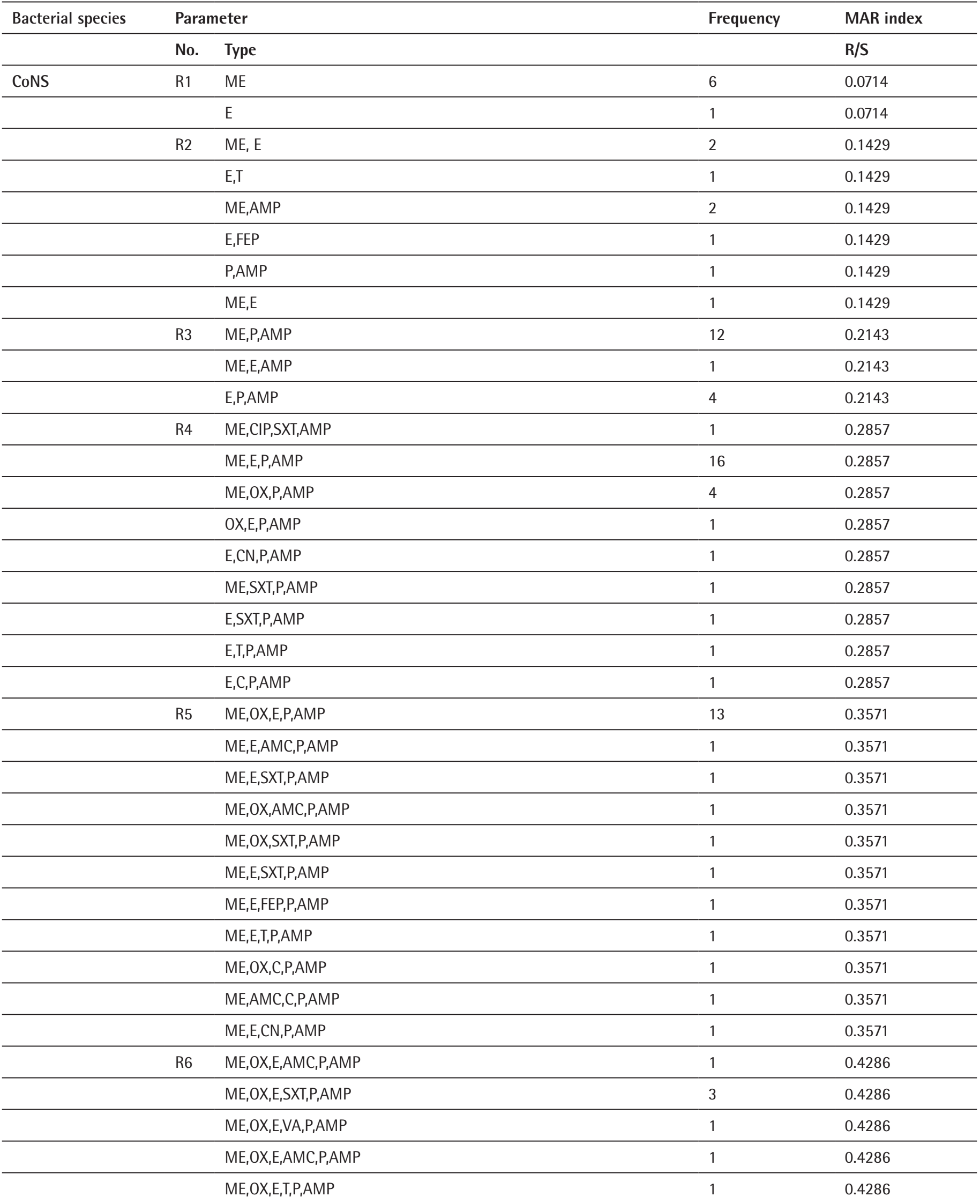


Table 7. Continued

\begin{tabular}{|c|c|c|c|c|}
\hline & & $M E_{1} O X_{1}, E_{1} S X T, P, A M P$ & 2 & 0.4286 \\
\hline & & ME,OX,AMC,FEP,P,AMP & 1 & 0.4286 \\
\hline & & $M E, O X, E, V A, P, A M P$ & 1 & 0.4286 \\
\hline & & ME,OX,E,T,P,AMP & 2 & 0.4286 \\
\hline & & ME,OX,AMC,C,P,AMP & 1 & 0.4286 \\
\hline & & $M E, E, T, C, P, A M P$ & 1 & 0.4286 \\
\hline \multirow{8}{*}{\multicolumn{2}{|c|}{ R7 }} & ME,OX,E,AMC,SXT,P,AMP & 1 & 0.5000 \\
\hline & & ME,OX,E,SXT,T,P,AMP & 1 & 0.5000 \\
\hline & & ME,OX,E,AMC,SXT,P,AMP & 1 & 0.5000 \\
\hline & & ME,OX,AMC,VA,FEP,P,AMP & 1 & 0.5000 \\
\hline & & ME,OX,E,AMC,T,P,AMP & 1 & 0.5000 \\
\hline & & $\mathrm{ME}, \mathrm{OX}, \mathrm{E}, \mathrm{VA}, \mathrm{T}, \mathrm{P}, \mathrm{AMP}$ & 1 & 0.5000 \\
\hline & & ME,OX,E,SXT,FEP,P,AMP & 1 & 0.5000 \\
\hline & & ME,E,AMC,SXT,FEP,P,APM & 1 & 0.5000 \\
\hline & R8 & ME,OX,E,AMC,SXT,T,P,AMP & 2 & 0.5714 \\
\hline & & ME,OX,E,XIP,NOR,SXT,P,AMP & 1 & 0.5714 \\
\hline & & ME,OX,E,AMC,VA,FEP,P,AMP & 1 & 0.5714 \\
\hline & $\mathrm{R} 10$ & ME,OX,E,CN,CIP,AMC,NOR,FEP,P,AMP & 2 & 0.7143 \\
\hline & $\mathrm{R} 11$ & ME,OX,E,CN,CIP,AMC,NOR,SXT,FEP,P,AMP & 1 & 0.7857 \\
\hline \multirow[t]{9}{*}{ S. aureus } & $\mathrm{R} 2$ & $\mathrm{ME}, \mathrm{E}$ & 1 & 0.1429 \\
\hline & R3 & ME,P,AMP & 3 & 0.2143 \\
\hline & R4 & ME,AMC,P,AMP & 2 & 0.2857 \\
\hline & & $M E, C, P, A M P$ & 1 & 0.2857 \\
\hline & $\mathrm{R} 5$ & $\mathrm{ME}, \mathrm{OX}, \mathrm{E}, \mathrm{P}, \mathrm{AMP}$ & 1 & 0.3571 \\
\hline & $\mathrm{R} 6$ & ME,E,SXT,T,P,AMP & 1 & 0.4286 \\
\hline & & ME,E,AMC,T,P,AMP & 1 & 0.4286 \\
\hline & R7 & ME,OX,E,T,C,P,AMP & 1 & 0.5000 \\
\hline & R8 & ME,E,CIP,NOR,SXT,T,P,AMP & 1 & 0.5714 \\
\hline
\end{tabular}

CoNS: Coagulase-negative staphylococcus, S. aureus: Staphylococcus aureus, P: Penicillin, AMP: Ampicillin, C: Chloramphenicol, T: Tetracycline, FEP: Cefepime, VA: Vancomycin, SXT: Trimethoprim/sulphamethoxazole, NOR: norfloxacin, AMC: Amoxicillin/clavulanic acid, CIP: ciprofloxacin, CN: Gentamicin, E: Erythromycin, OX: Oxacillin, ME: Methicillin

out of 29 isolates. None was effective against all the isolated 29 samples. Ten samples (35\%) of S. aureus showed MDR according to the Centers for Disease Control and Prevention (CDC) MDR definition. In total, 13 samples (45\%) of hospital-acquired MRSA were isolated according to Klevens et al. (2006) ${ }^{[12]}$.

CoNS bacteria were isolated from 99 samples including 31 $(31.3 \%)$ isolates from stethoscopes, $28(28.3 \%)$ isolates from mobile phones, and $40(40.4 \%)$ isolates from hands as shown in Table 6 . The hands and stethoscopes were highly contaminated, forming $72 \%$ of the total samples. CoNS expressed high resistance to penicillin, ampicillin, methicillin, and erythromycin. MDR bacteria, according to the CDC definition, were 27 (27\%) isolates divided as the following: 12 (44\%) isolates from stethoscopes, $10(37 \%)$ from the hands, and 5 (19\%) from mobile phones.

Of the 10 stethoscope samples with MDR bacteria, $6(12 \%)$ are resistant to at least 7 of the 14 antibiotics used. Chloramphenicol, gentamicin, vancomycin, and norfloxacin were highly effective against at least 92 (93\%) isolates. Chloramphenicol appeared to be most effective with only 3 isolates showing resistance, 
while vancomycin, norfloxacin, and gentamicin had only 4 isolates showing resistance from all isolated samples. Interestingly, 9 isolates were resistant to norfloxacin and ciprofloxacin antibiotics. None of the antibiotics used were effective against all isolates. Stethoscope samples showed a variable resistance profile. All stethoscopes and hand samples were sensitive to chloramphenicol. Additionally, one of the stethoscope isolates along with one of the mobile phone isolates was found to be resistant to 10 antibiotics including methicillin, oxacillin, erythromycin, gentamicin, ciprofloxacin, amoxicillin/clavulanic acid, norfloxacin, cefepime, penicillin, and ampicillin. Three stethoscope samples showed resistance to 8 antibiotics. In other stethoscope samples, vancomycin and gentamicin were effective against $30(97 \%)$, while norfloxacin and cefepime antibiotics showed sensitivity in 29 (94\%) isolates. All mobile phone samples showed sensitivity to vancomycin and trimethoprim/sulphamethoxazole. One of the hand isolates was resistant to 11 antibiotics, including methicillin, oxacillin, erythromycin, gentamicin, ciprofloxacin, amoxicillin/clavulanic acid, norfloxacin, trimethoprim/sulphamethoxazole, cefepime, penicillin, and ampicillin.

The MAR indexes of the isolated resistant bacteria were determined concerning 14 different antibiotics used in this study. The values of MAR indexes are shown in Table 7. The analysis of the MAR index of isolates revealed that most of the above-mentioned resistant bacteria, 0.2 ratios indicated the nature of high resistance of these isolates.

\section{Discussion}

The results regarding the frequency of cleaning stethoscopes in a single hospital setting in Jordan were slightly higher than those noted in other countries ${ }^{[13]}$, with the most frequently used method for cleaning stethoscopes being alcohol (34\%). The CDC recommends cleaning the stethoscopes with $70 \%$ alcohol after seeing each patient ${ }^{[14]}$. Interestingly, Genné et al. (1996) ${ }^{[15]}$ showed that after $>1$ day without cleaning the stethoscope, the contamination level rose from $0 \%$ to $69 \%$, leading to the recommendation by Saloojee and Steenhoff $2001^{[16]}$ to clean stethoscopes with alcohol at least once daily. The majority of students and healthcare workers are aware of the role of stethoscopes in the transmission of infectious organisms from one patient to another ${ }^{[17]}$. Similarly, $78.2 \%$ of our students considered the stethoscope as a risk for infection transmission.

The current study revealed that 13\% of students said that they saw others clean their stethoscope, which compares with 8.1\% of Serbian $4^{\text {th }}$ and $6^{\text {th }}$-year medical students ${ }^{[17]}$ and in only $1.3 \%$ of the United Kingdom medical students ${ }^{[13]}$. Of the students, $67 \%$ are unaware of how to effectively clean their stethoscope, which is with a complete agreement with Jayarajah et al. in $2019^{[18]}$ who revealed that the majority of South Asian students did not know the proper way or the recommendations for equipment hygiene. Additionally, only $8 \%$ of medical students had attended lectures or training on stethoscope cleaning, which is approximately similar to the finding of Gazibara et al. ${ }^{[17]}$ in 2015 (8.5\%), but more than that of Saunders et al.'s ${ }^{[13]}$ findings (2.9\%). Therefore, increasing the number of lectures on stethoscope hygiene is recommended, which is very effective and inexpensive, to improve stethoscope cleaning compliance among students ${ }^{[19]}$. Of the students, 78\% washed their hands after a patient encounter, which is consistent with other observations that hand hygiene was good among students (69.2-78\%) who had a moderate knowledge of hand hygiene practices that improved with the progression of training ${ }^{[16]}$. Studies show that hand washing is the simplest and most effective method to reduce contamination ${ }^{[20]}$. Currently, mobile phones are considered as a potential carrier of pathogenic bacteria ${ }^{[21]}$; however, $86 \%$ of the students still used their mobile phones during rotations, and only 29\% clean them after rotations. CoNS belong to Staphylococci genera and are part of the human normal flora, mainly inhabiting the skin; however, they can colonize the upper respiratory tract, the gastrointestinal tract, the genitourinary tract, and mammary glands leading to serious infections associated with healthcare facilities and the community ${ }^{[22]}$.

This study revealed that the majority of the isolates [99 (76\%)] were identified as CoNS followed by Staphylococcus aureus [29 (22\%)]. Isolation rates were $31.3 \%$ CoNS and $27.5 \%$ S. aureus from stethoscopes, $28.3 \%$ CoNS and $45 \%$ S. aureus from mobile phones, and $40.4 \%$ CoNS and 27.5\% S. aureus from hands.

A study by Senthil et al. in $2017^{[23]}$ revealed the isolation rate of CoNS and S. aureus from students' hands as $32 \%$ and $68 \%$, respectively. A study of students' mobile phones produced almost the opposite results as regards bacterial species ${ }^{[21]}$. Regarding the stethoscopes, a study from Spain that was conducted by clinicians and nurses showed that CoNS was isolated from the diaphragms at a rate of $97 \%$ and S. aureus at a rate of $5 \% \%^{[24]}$. Another study on students' stethoscopes in the UK gave an isolation rate of $89 \%$ for CoNS and $12 \%$ for S. aureus ${ }^{[25]}$. In Greece, the isolation rate of CoNS from physicians' stethoscopes was $96.6 \%$ and that of $\mathrm{S}$. aureus was $6.8 \%{ }^{[26]}$.

The vast majority of isolated CoNS in this study were resistant to penicillin, ampicillin, and methicillin, which is a common finding in other studies ${ }^{[27]}$. A study from Ethiopia revealed an approximately $65 \%$ of the isolated CoNS were resistant to penicillin ${ }^{[28]}$. However, a study in Greece showed that approximately $12 \%$ of the isolated CoNS were resistant to methicillin ${ }^{[26]}$.

The isolation rate and antimicrobial resistance profile of CoNS are quite alarming since those isolates have more adoption 
towards hospital settings, are more persistent, and can spread within and between hospitals ${ }^{[29]}$. Moreover, CoNS are identified in 33-60\% of culture isolates obtained from neonates who suffered HCAls, although no neonatal deaths were linked to CoNS; however, neonates had comorbidities, mainly congenital heart diseases ${ }^{[30]}$.

Thirteen S. aureus isolates were considered MRSA according to their antimicrobial resistance profile. S. aureus is considered the leading cause of nosocomial infections, primarily causing lower respiratory tract infections, surgical site infections, pneumonia, and cardiovascular infections ${ }^{[31]}$, and is the second leading cause of nosocomial bacteremia ${ }^{[32]}$. Infections with S. aureus are especially hard to treat due to the acquired resistance to antimicrobials. Resistance to penicillin and other narrow-spectrum $\beta$-lactamase-resistant antimicrobials, such as methicillin and oxacillin, appeared shortly after their introduction into the clinical practice ${ }^{[33]}$.

The increased incidence of MRSA in hospitals is likely to increase the demand for vancomycin. Trimethoprim-sulfamethoxazole is available for MRSA treatment; however, vancomycin is still the drug of choice ${ }^{[34]}$. This pattern will complicate future control of MRSA, as resistance to vancomycin is already emerging ${ }^{[35]}$. The use of vancomycin should be restricted in MRSA infections when no other drug is effective to solve this issue ${ }^{[36]}$.

The cleaning process, when correctly done, should dramatically reduce the contamination levels. When swabs were taken from 10 stethoscopes before and after the cleaning process, cultures revealed a significant drop of colony-forming units from an average of 27 to 1 . Moreover, hand washing has been long shown to be the leading practice to limit the spread of $\mathrm{HCAls}^{[37]}$.

The MAR indexes of the isolated resistant bacteria were determined concerning 14 different used antibiotics in this study. The values of MAR indexes are shown in Table 6 . The analysis of the MAR index of isolates showed that 97 of the total 99 CONS and 11 of 29 S. aureus had MAR of $>0.2$, indicating high resistance of these isolates. High resistance in the current study may suggest that isolates originated from highly resistant sources where antibiotics are often used without a physician's prescription. Healthcare professionals who misuse antibiotics by following non-standardized practices could be another major factor $^{[38]}$.

The major limitations of our study were the low number of students attending the training at the hospital due to the strict regulations applied after the coronavirus disease-2019 pandemic, as well as the lack of financial support.

\section{Conclusion}

The current study revealed a gap between the students' knowledge and their proper hygienic practice in the hospitals. Poor hand hygiene, which is routinely discussed in lectures, appeared to be a major source of infection transmission. Medical and nursing students should always be aware of the new methods of bacterial transmission and infection control; however, a high percentage of them stated that they did not have any idea about the importance of disinfecting their stethoscopes and mobile phones. The present study provides evidence that the hands are the major source of pathogenic bacteria and have higher bacterial contamination than stethoscopes and mobile phones. It highlights the need for increasing awareness among students and healthcare professionals about the importance of disinfecting medical devices, mobile phones, and hands in hospitals.

\section{Acknowledgment}

The authors would like to thank Batool Alhasan and Walaa Almdallal for their technical assistance in collecting the samples.

\section{Ethics}

Ethics Committee Approval: The study protocol was approved by the Institutional Ethics Council at Yarmouk University under the number (IRB/2021/13).

Informed Consent: Consent form was filled out by all participants.

Peer-review: Externally and internally peer-reviewed.

\section{Authorship Contributions}

Concept: W.Al.M., Design: W.Al.M., L.A.-I., Data Collection or Processing: A.K., D.A.I., M.K., Analysis or Interpretation: N.B., L.A.-I., A.K., I.M., Literature Search: L.A.-I., A.K., D.A.I., M.K., Writing: N.B., W.Al.M., I.M., M.S.

Conflict of Interest: No conflict of interest was declared by the authors.

Financial Disclosure: The authors declared that this study received no financial support.

\section{References}

1. Allegranzi B, Bagheri Nejad S, Combescure C, Graafmans W, Attar $H_{\text {, }}$ Donaldson L, Pittet D. Burden of endemic health-care-associated infection in developing countries: systematic review and meta-analysis. Lancet. 2011;377:228-41.

2. Marchetti A, Rossiter R. Economic burden of healthcare-associated infection in US acute care hospitals: societal perspective. J Med Econ. 2013;16:1399404.

3. Mathur P. Hand hygiene: back to the basics of infection control. Indian J Med Res. 2011;134:611-20. 
4. Brady RR, Hunt AC, Visvanathan A, Rodrigues MA, Graham C, Rae C, Kalima P, Paterson HM, Gibb AP. Mobile phone technology and hospitalized patients: a cross-sectional surveillance study of bacterial colonization, and patient opinions and behaviours. Clin Microbiol Infect. 2011;17:830-5.

5. Loftus MJ, Guitart C, Tartari E, Stewardson AJ, Amer F, Bellissimo-Rodrigues F, Lee YF, Mehtar S, Sithole BL, Pittet D. Hand hygiene in low- and middleincome countries. Int J Infect Dis. 2019;86;25-30.

6. Brady RR, Wasson A, Stirling I, McAllister C, Damani NN. Is your phone bugged? The incidence of bacteria known to cause nosocomial infection on healthcare workers' mobile phones. J Hosp Infect. 2006;62:123-5.

7. Ahmed K, Shaikh S, Rehman R, Ali SM. Frequency Of Awareness And Practice Of Stethoscope Hygiene With Regards To Guide Line Among Medical Students, Residents And Doctors In Karachi. J Bahria Univ Med Dent Coll. 2018;8:31-4.

8. Sumritivanicha A, Chintanavilas K, Apisarnthanarak A. Prevalence and type of microorganisms isolated from house staff's mobile phones before and after alcohol cleaning. Infect Control Hosp Epidemiol. 2011;32:633-4.

9. Boulée D, Kalra S, Haddock A, Johnson TD and Peacock WF. Contemporary stethoscope cleaning practices: What we haven't learned in 150 years. Am J Infect Control. 2019;47:238-42.

10. Al Momani W, Khatatbeh M, Altaany Z. Antibiotic susceptibility of bacterial pathogens recovered from the hand and mobile phones of university students. Germs. 2019;9:9-16.

11. Hiramatsu K, Katayama Y, Matsuo M, Sasaki T, Morimoto Y, Sekiguchi A, Baba T. Multi-drug-resistant Staphylococcus aureus and future chemotherapy. J Infect Chemother. 2014;20:593-601.

12. Klevens RM, Edwards JR, Tenover FC, McDonald LC, Horan T, Gaynes R; National Nosocomial Infections Surveillance System. Changes in the epidemiology of methicillin-resistant Staphylococcus aureus in intensive care unit in US hospitals, 1992-2003. Clin Infect Dis. 2006;42:389-91.

13. Saunders C, Hryhorskyj L, Skinner J. Factors influencing stethoscope cleanliness among clinical medical students. J Hosp Infect. 2013;84:242-4.

14. Centers for Disease Control and Prevention. Laboratory Detection of: Oxacillin/ Methicillin-resistant Staphylococcus aureus. 2019. Available from: https://www.cdc.gov/mrsa/lab/index.html\# anchor_ 1548429322

15. Genné D, de Torrenté A, Humair L, Siegrist HH. [Level of stethoscope contamination in the hospital environment]. Schweiz Med Wochenschr. 1996;126:2237-40.

16. Saloojee $H$, Steenhoff A. The health professional's role in preventing nosocomial infections. Postgrad Med J. 2001;77:16-9.

17. Gazibara T, Radovanovic S, Maric G, Rancic B, Kisic-Tepavcevic D, Pekmezovic T. Stethoscope Hygiene: Practice and Attitude of Medical Students. Med Princ Pract. 2015;24:509-14.

18. Jayarajah U, Athapathu AS, Jayawardane BAAJ, Prasanth S, Seneviratne SN. Hygiene practices during clinical training: Knowledge, attitudes and practice among a cohort of South Asian Medical students. BMC Med Educ. 2019;19:157.

19. Uneke CJ, Ndukwe CD, Nwakpu KO, Nnabu RC, Ugwuoru CD, PrasopaPlaizier N. Stethoscope disinfection campaign in a Nigerian teaching hospital: results of a before-and-after study. J Infect Dev Ctries. 2014;8:8693.

20. Pittet D. Improving Compliance With Hand Hygiene in Hospitals. Infect Control Hosp Epidemiol. 2000;21:381-6.

21. Zakai $S$, Mashat $A$, Abumohssin $A$, Samarkandi A, Almaghrabi B, Barradah $H$, Jiman-Fatani A. Bacterial contamination of cell phones of medical students at King Abdulaziz University, Jeddah, Saudi Arabia. J Microsc Ultrastruct. 2016;4:143-6.
22. Toltzis P. Staphylococcus epidermidis and Other Coagulase Negative Staphylococci. Principles and Practice of Pediatric Infectious Diseases, 2018:706-12.

23. Senthil S, Hegde A, Kulkarni V, Radhakrishna M. Bacterial contamination of hands of medical interns and undergraduate students. Asian J Pharm Clin Res. 2017;10:145-9.

24. Núñez $S$, Moreno A, Green K, Villar J. The stethoscope in the Emergency Department: a vector of infection. Epidemiol Infect. 2000;124:233-7.

25. Mitchell A, Dealwis N, Collins J, Chew K, Taylor R, Schwab U, Narayanan M. Stethoscope or "Staphoscope"? Infection by auscultation. J Hosp Infect. 2010;76:278-9.

26. Fafliora E, Bampalis VG, Lazarou N, Mantzouranis G, Anastassiou ED, Spiliopoulou I, Christofidou M. Bacterial contamination of medical devices in a Greek emergency department: impact of physicians' cleaning habits. Am J Infect Control. 2014;42:807-9.

27. Archer GL, Climo MW. Antimicrobial susceptibility of coagulase-negative staphylococci. Antimicrob Agents Chemother. 1994;38:2231-7.

28. Worku T, Derseh D, Kumalo A. Bacterial Profile and Antimicrobial Susceptibility Pattern of the Isolates from Stethoscope, Thermometer, and Inanimate Surfaces of Mizan-Tepi University Teaching Hospital, Southwest Ethiopia. Int J Microbiol. 2018;2018:9824251.

29. Botelho AMN, Nunes ZDG, Asensi MD, Gomes MZR, Fracalanzza SEL, Figueiredo AMS. Characterization of coagulase-negative staphylococci isolated from hospital indoor air and a comparative analysis between airborne and inpatient isolates of Staphylococcus epidermidis. J Med Microbiol. 2012;61:1136-45.

30. da Silva AR, Simões ML, Werneck Ldos S, Teixeira CH. Healthcare associated infections caused by coagulase-negative Staphylococci in a neonatal intensive care unit. Rev Bras Ter Intensiva. 2013;25:239-44.

31. Richards MJ, Edwards JR, Culver DH, Gaynes RP. Nosocomial infections in medical intensive care units in the United States. National Nosocomial Infections Surveillance System. Crit Care Med. 1999;27:887-92.

32. Wisplinghoff $H$, Bischoff $T$, Tallent $S M$, Seifert $H$, Wenzel RP, Edmond MB. Nosocomial bloodstream infections in US hospitals: analysis of 24,179 cases from a prospective nationwide surveillance study. Clin Infect Dis. 2004;39:309-17.

33. Lowy FD. Antimicrobial resistance: the example of Staphylococcus aureus. J Clin Invest. 2003;11:1265-73.

34. Freidlin J, Acharya N, Lietman TM, Cevallos V, Whitcher JP, Margolis TP. Spectrum of eye disease caused by methicillin-resistant Staphylococcus aureus. Am J Ophthalmol. 2007;144:313-5.

35. Sieradzki K, Roberts RB, Haber SW, Tomasz A. The development of vancomycin resistance in a patient with methicillin-resistant Staphylococcus aureus infection. N Engl J Med. 1999;340:517-23.

36. Klein $E_{1}$ Smith DL, Laxminarayan R. Hospitalizations and deaths caused by methicillin-resistant Staphylococcus aureus, United States, 1999-2005. Emerg Infect Dis. 2007;13:1840-6.

37. Boyce JM, Pittet D; Healthcare Infection Control Practices Advisory Committee; HICPAC/SHEA/APIC/IDSA Hand Hygiene Task Force. Guideline for hand hygiene in health-care settings. Recommendations of the Healthcare Infection Control Practices Advisory Committee and the HIPAC/ SHEA/APIC/IDSA Hand Hygiene Task Force. Am J Infect Control. 2002;30:146.

38. Yadesa TM, Gudina EK, Angamo MT. Antimicrobial use-related problems and predictors among hospitalized medical in-patients in Southwest Ethiopia: prospective observational study. PLoS One. 2015;10:e0138385. 